\title{
Avicularin inhibits cell proliferation and induces cell apoptosis in cutaneous squamous cell carcinoma
}

\author{
YAN WANG ${ }^{1}$, MINGZHU LIU ${ }^{2}$, SHENGLAN CHEN $^{1}$ and QIN WU ${ }^{1}$ \\ ${ }^{1}$ College of Medical Technology, Jiangsu Vocational College of Medicine, Yancheng, Jiangsu 224000; \\ ${ }^{2}$ Department of Dermatology, Nanjing Integrated Traditional Chinese and Western Medicine Hospital Affiliated to \\ Nanjing University of Chinese Medicine, Nanjing, Jiangsu 210014, P.R. China
}

Received December 8, 2018; Accepted November 19, 2019

DOI: $10.3892 /$ etm.2019.8303

\begin{abstract}
Avicularin (AL), quercetin-3- $\alpha$-L-arabinofur anoside, has various pharmacological properties such as anticancer and anti-infective effects. However, the potential molecular mechanism via which AL exerts its anticancer activity is not fully understood. Cutaneous squamous cell carcinoma (CSCC) is the second most common skin cancer, where metastasis has resulted in in effective clinical treatments. The aim of the present in vitro study was to investigate the anticancer effects and underlying mechanism of AL on human CSCC. The present results suggested that AL dose-dependently inhibited SCC13 cell viability and induced apoptosis. In addition, the present results suggested that AL induced apoptosis via repression of the mitogen-activated protein kinase kinase (MEK)/NF- $\kappa \mathrm{B}$ signal pathway, thereby affecting the expression of apoptosis-related genes. Bax expression level was increased, while $\mathrm{Bcl}-2$ expression level was decreased in SCC13 cells following AL treatment. In addition, the MEK/NF- $\mathrm{BB}$ signaling pathway-related genes p-MEK and phosphorylated-p65 were also decreased. The present results suggested that AL treatment increased the expression level of E-cadherin, but decreased the expression levels of N-cadherin, matrix metalloproteinase (MMP)-9 and vimentin in SCC13 cells. Collectively, the present results suggested that AL may have an anti-CSCC effect by inhibiting cell viability, inducing apoptosis and inhibiting epithelial-mesenchymal transition (EMT) of CSCC cells. The mechanism of these anti-CSCC effects was suggested to be via the regulation of apoptosis-related genes and EMT-related genes, and the inhibition of the MEK/NF- $\mathrm{B}$ signaling pathway.
\end{abstract}

Correspondence to: Dr Qin Wu, College of Medical Technology, Jiangsu Vocational College of Medicine, 283 Jiefang South Road, Yancheng, Jiangsu 224000, P.R. China

E-mail: wuqin201718@163.com

Key words: avicularin, proliferation, apoptosis, cutaneous squamous cell carcinoma

\section{Introduction}

Cutaneous squamous cell carcinoma (CSCC), which represents $20 \%$ of all cutaneous malignancies, is the second most common skin cancer (1-3). In addition, the incidence of CSCC is rising in the UK, with the mean annual increase of 5\% between 2013 and 2015 (4). Although CSCC commonly occurs on the skin of the head and neck (5), there is also a risk of occurrence in the lymph nodes and metastasis to other organs $(3,6)$. Patients with metastatic CSCC have a poor prognosis (6). The standard treatment for CSCC is systemic chemotherapy $(6,7)$; the platinum compound cisplatin used either alone or in combination with other agents is regarded as a standard chemotherapeutic agent for CSCC therapy (8). However, cisplatin treatment may induce a variety of side effects, including eventual resistance to cisplatin and the relapse of most cancer types after therapy (9). Therefore, novel and effective anti-CSCC therapeutic strategies are urgently required.

Natural herbal medicines have been used as anticancer agents (10). Avicularin (AL), a bioactive flavonol, can be isolated from many medicinal herbs, including Lespedeza cuneata, Lindera erythrocarpa and Psidium guajava (11). AL exhibits diverse pharmacological properties including antioxidant, antiallergic, anti-inflammatory, hepatoprotective and antitumor effects (12-14). AL has been found to have a significant role in reducing the progression of type 2 diabetes (15). The biological activities of other flavonols, such as quercetin in the aglycone form have been investigated as a possible treatment strategy for cancer, including breast cancer and leukemia (16). However, the biological properties of AL are not fully understood, therefore the present study examined the role of AL in regulating CSCC development.

The present study investigated the effect of AL on CSCC cells. The present results suggested that AL significantly inhibited proliferation and increased apoptosis in CSCC cells. In addition, AL significantly suppressed the $\mathrm{MEK} / \mathrm{NF}-\kappa \mathrm{B}$ signaling pathway in a concentration-dependent manner.

\section{Materials and methods}

Cell culture and treatment. DMEM (Gibco; Thermo Fisher Scientific, Inc) with $10 \%$ FBS (Gemini Bio-Products, Inc.), $10 \mathrm{U} / \mathrm{ml}$ penicillin- $\mathrm{G}$ and $10 \mathrm{mg} / \mathrm{ml}$ streptomycin (Gemini 
Bio-Products, Inc.) was used to culture the CSCC cell line SCC13 (kind gift from Dr James Rheinwald, Brigham and Women's Hospital, Harvard Medical School, Boston, MA, USA) at $37^{\circ} \mathrm{C}$ with $5 \% \mathrm{CO}_{2}$. $\mathrm{SCC} 13$ cells were treated with different concentrations of $\mathrm{AL}(0,10,30,100$ or $300 \mu \mathrm{M}$; purity $>99 \%$; Chengdu Best-Reagent Chemical, Co., Ltd.) (17) at $37^{\circ} \mathrm{C}$ for 24,48 and $72 \mathrm{~h}$ (18) prior to subsequent experimentation.

Cell Counting Kit-8 (CCK-8) cell viability assay. A CCK-8 assay (Dojindo Molecular Technologies, Inc.) was used to measure cell viability according to the manufacturer's protocol. SCC13 cells were plated into 96 -well plates at $5 \times 10^{3}$ cells/well and incubated at $37^{\circ} \mathrm{C}$ for $24 \mathrm{~h}$. Subsequently, the cells were treated with various concentrations $(0,10,30,100$ or $300 \mu \mathrm{M})$ of $\mathrm{AL}$ for 24,48 and $72 \mathrm{~h}$ at $37^{\circ} \mathrm{C}$. Then, $10 \mu \mathrm{l} \mathrm{CCK}-8$ assay solution was added to each well (Dojindo Molecular Technologies, Inc.) and the wells were incubated at $37^{\circ} \mathrm{C}$ for a $1 \mathrm{~h}$. A microplate reader (Synergy2; BioTeK Instruments, Inc.) was used to measure the optical density at $450 \mathrm{~nm}$. The $\mathrm{IC}_{50}$ value of $\mathrm{AL}$ to $\mathrm{SCC} 13$ cells at $48 \mathrm{~h}$ was calculated. Each experiment was performed in triplicate.

Apoptosis analysis. To detect SCC13 cell apoptosis, the cells were treated with or without different concentrations of $\mathrm{AL}$ $(10,30,100$ or $300 \mu \mathrm{M})$ at $37^{\circ} \mathrm{C}$ for $48 \mathrm{~h}$. Then, $5 \mu \mathrm{l}$ Annexin V-FITC and $10 \mu \mathrm{l}$ propidium iodide (cat. no. 70-AP101-100; Hangzhou Multi Sciences Biotech Co., Ltd.) were used to stain the cells at room temperature for $30 \mathrm{~min}$ following the manufacturer's protocol. Cell apoptosis was analyzed using a BD FACSCalibur ${ }^{\mathrm{TM}}$ flow cytometer (Becton, Dickinson and Company) and WinMDI software (version 2.5; Purdue University Cytometry Laboratories) was used to analyze the data.

Western blot analysis. SCC13 cells were treated with or without $\mathrm{AL}(10,30,100$ or $300 \mu \mathrm{M})$ at $37^{\circ} \mathrm{C}$ for $48 \mathrm{~h}$. Total cellular proteins from SCC13 cells were extracted using RIPA buffer (Beyotime Institute of Biotechnology) supplemented with protease inhibitor (Beyotime Institute of Biotechnology). A bicinchoninic acid protein assay kit (Pierce; Thermo Fisher Scientific, Inc.) was used to evaluate the protein concentrations and $100^{\circ} \mathrm{C}$ water was used to heat the samples for $10 \mathrm{~min}$ to denature the proteins. Then, $12 \%$ SDS-PAGE gels were used to separate the proteins ( $40 \mu \mathrm{g}$ per lane), which were then electrophoretically transferred to PVDF membranes (EMD Millipore). Membranes were blocked at room temperature for $1 \mathrm{~h}$ with 5\% non-fat milk and blotted overnight at $4^{\circ} \mathrm{C}$ with the following primary antibodies (all from Cell Signaling Technology, Inc.): E-cadherin (1:1,000; cat no. 3195), N-cadherin (1:1,000; cat no. 13116), matrix metalloproteinase (MMP-9; 1:1,000; cat no. 13667), vimentin (1:1,000; cat no. 12826), Bcl-2 (1:1,000; cat no. 4223), Bax (1:1,000; cat no. 5023), phosphorylated (p)-mitogen-activated protein kinase kinase (p-MEK; 1:1,000; cat no. 3958), MEK (1:1,000; cat no. 8727), p-p65 (1:1,000; cat no. 3033), p65 (1:1,000; cat no. 8242) and $\beta$-actin (1:1,000; cat no. 4970). Membranes were then incubated with the anti-rabbit IgG horseradish peroxidase-linked secondary antibody (cat no. 7074; 1:2,000; Cell Signaling Technology, Inc.) for $2.5 \mathrm{~h}$ at room temperature. Enhanced chemiluminescence reagent (EMD Millipore) was used to visualize the protein

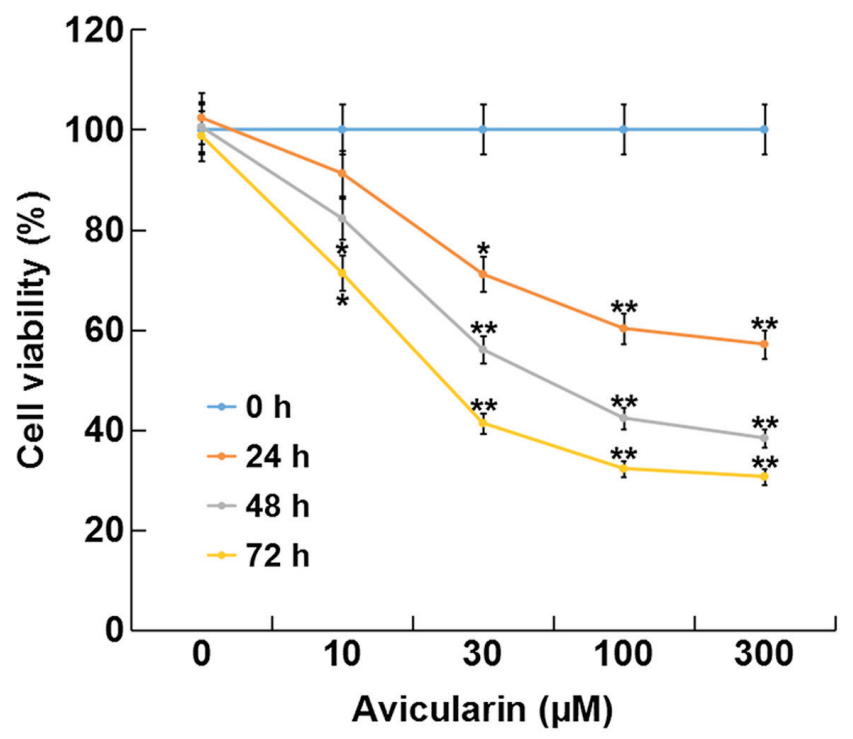

Figure 1. Avicularin inhibits cell viability of SCC13 cells. SCC13 cells were treated with different concentrations of avicularin $(0,10,30,100$ or $300 \mu \mathrm{M})$ for 24,48 and $72 \mathrm{~h}$, and then a Cell Counting Kit- 8 assay was used to detect cell viability. Data are presented as the mean $\pm \mathrm{SD}$. ${ }^{*} \mathrm{P}<0.05,{ }^{* *} \mathrm{P}<0.01$ vs. $0 \mu \mathrm{M}$ avicularin.

bands. The band density was quantified with Gel-Pro Analyzer densitometry software (version 6.3; Media Cybernetics, Inc.).

Reverse transcription-quantitative PCR (RT-qPCR). TRIzol ${ }^{\circledR}$ reagent (Invitrogen; Thermo Fisher Scientific, Inc.) was used to prepare the total RNA from SCC13 cells according to the manufacturer's protocol. A PrimeScript ${ }^{\mathrm{TM}} \mathrm{RT}$ reagent kit (Takara Bio, Inc.) was used to perform the RT. The temperature protocol for the reverse transcription reaction was as follows: Primer annealing at $25^{\circ} \mathrm{C}$ for $5 \mathrm{~min}$, cDNA synthesis at $42^{\circ} \mathrm{C}$ for $60 \mathrm{~min}$ and termination at $80^{\circ} \mathrm{C}$ for $2 \mathrm{~min}$. qPCR analysis was carried out using SYBR Premix Ex Taq II (Takara Bio, Inc.) following the manufacturer's instructions. The reaction conditions for PCR were: Initial denaturation at $95^{\circ} \mathrm{C}$ for $10 \mathrm{~min}$, followed by 40 cycles of $15 \mathrm{sec}$ at $95^{\circ} \mathrm{C}$, $72^{\circ} \mathrm{C}$ for $30 \mathrm{sec}$ and $78^{\circ} \mathrm{C}$ for $1.5 \mathrm{~min}$. GAPDH was used as an internal control. All PCR primer sequences were obtained as required and listed as follows: E-cadherin forward, 5'-CGA GAGCTACACGTTCACGG-3' and reverse, 5'-GGGTGT CGAGGGAAAAATAGG-3'; N-cadherin forward, 5'-TTT GATGGAGGTCTCCTAACACC-3' and reverse, 5'-ACGTTT AACACGTTGGAAATGTG-3'; MMP-9 forward, 5'-AGA CCTGGGCAGATTCCAAAC3' and reverse, 5'-CGGCAA GTCTTCCGAGTAGT-3'; vimentin forward, 5'-GACGCC ATCAACACCGAGTT-3' and reverse, 5'-CTTTGTCGTTGG TTAGCTGGT-3'; Bcl-2, forward 5'-TTGGATCAGGGA GTTGGA AG-3' and reverse, 5'-TGTCCCTACCAACCA GAAGG-3' and Bax forward, 5'-CGTCCACCAAGAAGC TGAGCG-3' and reverse, 5'-CGTCCACCAAGAAGCTGA GCG-3'. The $2^{-\Delta \Delta C q}$ quantification method (19) was used to analyze the relative gene expression.

Statistical analysis. Data are presented as the mean \pm SD. SPSS 16.0 software (SPSS, Inc.) was used to perform the statistical analysis. One-way ANOVA test followed by Tukey's 

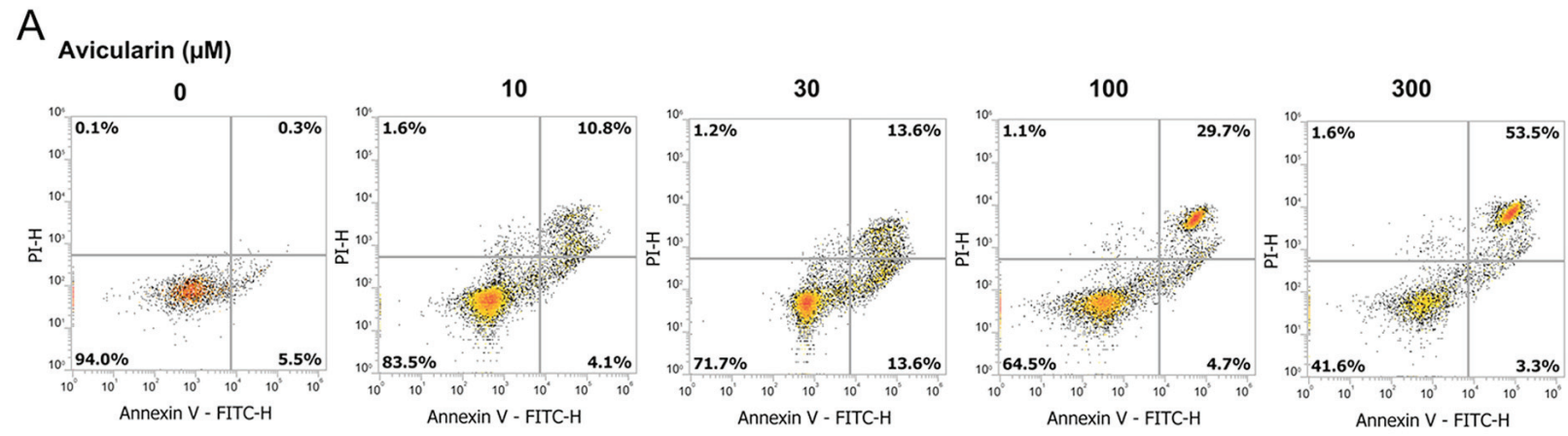

B

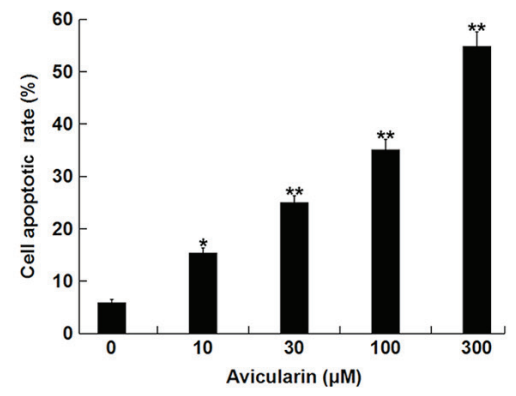

Figure 2. Avicularin induces apoptosis in SCC13 cells. (A) SCC13 cells were treated with different concentrations of avicularin ( 0 , $10,30,100$ or $300 \mu \mathrm{M})$ for $48 \mathrm{~h}$. Then, flow cytometry analysis with Annexin V-FITC and PI staining was used to detect the apoptotic rate in cells. (B) Quantification of cell apoptotic rate. Data are presented as the mean $\pm \mathrm{SD} .{ }^{*} \mathrm{P}<0.05,{ }^{* *} \mathrm{P}<0.01$ vs. $0 \mu \mathrm{M}$ avicularin.

post hoc test was used to assess the differences between multiple groups. $\mathrm{P}<0.05$ was considered to indicate a statistically significant difference.

\section{Results}

AL inhibits SCC13 cell viability. The present study investigated the effect of AL on CSCC cell viability using a CCK-8 assay. The present results suggested that treatment with $\mathrm{AL}$ at different concentrations $(10,30,100$ or $300 \mu \mathrm{M})$ for 24,48 and $72 \mathrm{~h}$ significantly inhibited cell viability in a dose- and time-dependent manner compared with control cells without AL treatment (Fig. 1). The present results suggested that AL had cytotoxic effects on SCC13 cells in a dose- and time-dependent manner. In addition, the present results indicated that the $\mathrm{IC}_{50}$ for $48 \mathrm{~h}$ of $\mathrm{AL}$ in the SCC13 cells was $80.27 \mu \mathrm{M}$.

AL increases the apoptotic rate of SCC13 cells. The present study investigated whether AL affected CSCC cell apoptosis. SCC13 cells were treated with different concentrations of AL $(10,30,100$ or $300 \mu \mathrm{M})$ for $48 \mathrm{~h}$, and then cell apoptosis was analyzed. AL dose-dependently increased the apoptotic ratio of SCC13 cells (Fig. 2). Therefore, the present results suggested that AL increased CSCC cell apoptosis.

Avicularin regulates the epithelial-mesenchymal transition (EMT) of SCC13 cells. To investigate whether AL has a role in EMT regulation, the present study evaluated the expression levels of the EMT markers E-cadherin, N-cadherin, MMP-9 and vimentin. The present results suggested that AL increased E-cadherin protein expression level and decreased $\mathrm{N}$-cadherin, MMP-9 and vimentin protein expression levels in SCC13 cells in a dose-dependent manner (Fig. 3A-E). Similar results for the mRNA expression levels were indicated by RT-qPCR analysis (Fig. 3F-I).

Avicularin regulates the expression levels of apoptosis-related genes and suppresses the $M E K / N F-\kappa B$ signaling pathway. The present study investigated the molecular mechanisms by which AL may affect SCC13 cells. SCC13 cells were treated with different concentrations of $\mathrm{AL}$ for $48 \mathrm{~h}$, and then the expression levels of Bcl-2 and Bax and the relative proteins in $\mathrm{MEK} / \mathrm{NF}-\kappa \mathrm{B}$ signaling pathway were measured. The present results suggested that $\mathrm{Bcl}-2$, which plays an important role in apoptosis (20), was decreased in SCC13 cells after AL treatment (Fig. 4A and B). In addition, Bax protein expression level was significantly increased by $\mathrm{AL}$ treatment in a dose-dependent manner (Fig. 4A and C). A similar result was identified at the mRNA expression level of Bcl-2 and Bax (Fig. 4D and E). Moreover, the expression levels of the $\mathrm{MEK} / \mathrm{NF}-\kappa \mathrm{B}$ signaling-related proteins $\mathrm{p}-\mathrm{MEK}$ and $\mathrm{p}-\mathrm{p} 65$ were significantly decreased (Fig. 5A-C), while AL treatment had no significant effect on the mRNA expression levels of MEK and p65 in SCC13 cells (Fig. 5D and E).

\section{Discussion}

A large number of flavonoids, which are natural plant polyphenols, are found in fruits and vegetables (11-14). Naturally occurring flavonoids are a promising source for drug development, as they have been shown to have anticancer, antioxidant, anti-inflammatory and neuroprotective effects $(18,21)$. Aglycone forms of flavonoid exhibit a more potent free radical scavenging activity compared with their 
A

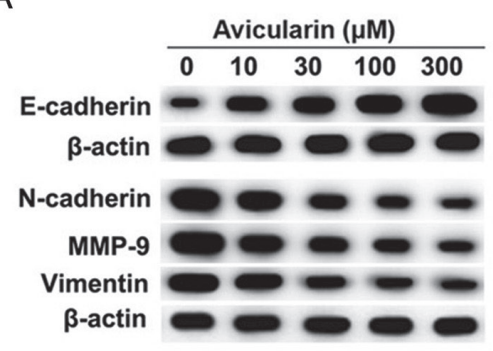

C

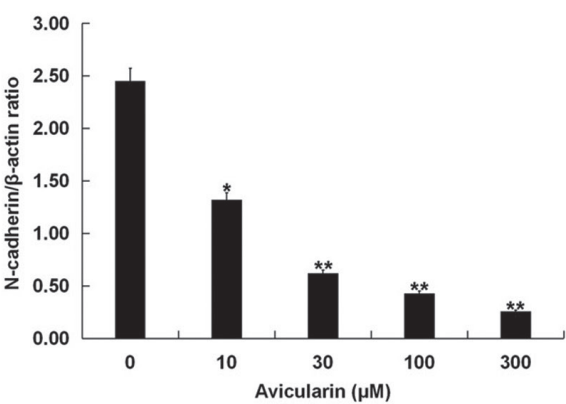

$\mathrm{E}$

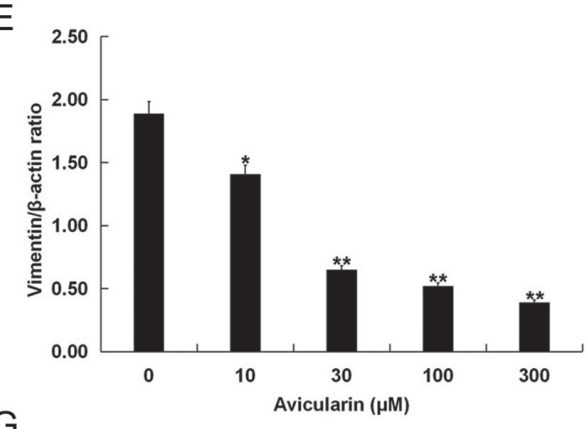

G

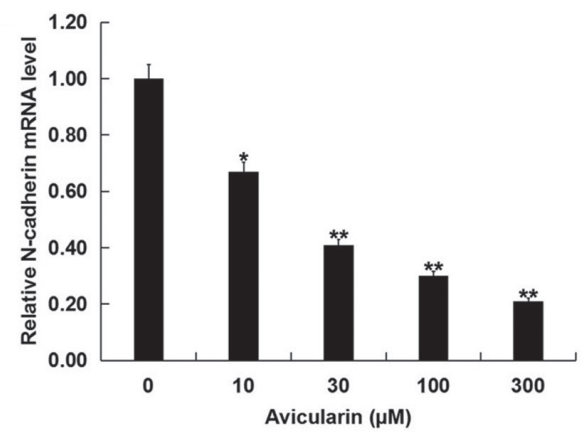

1

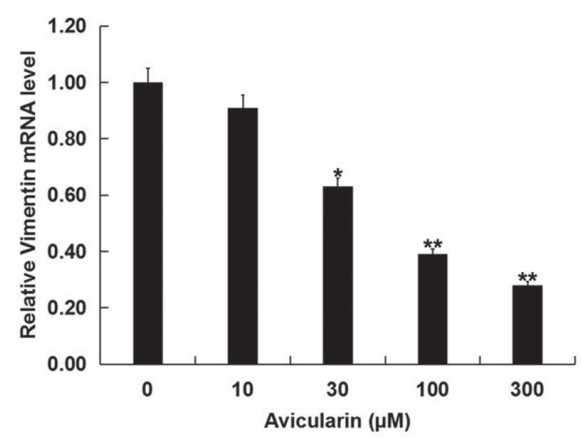

B
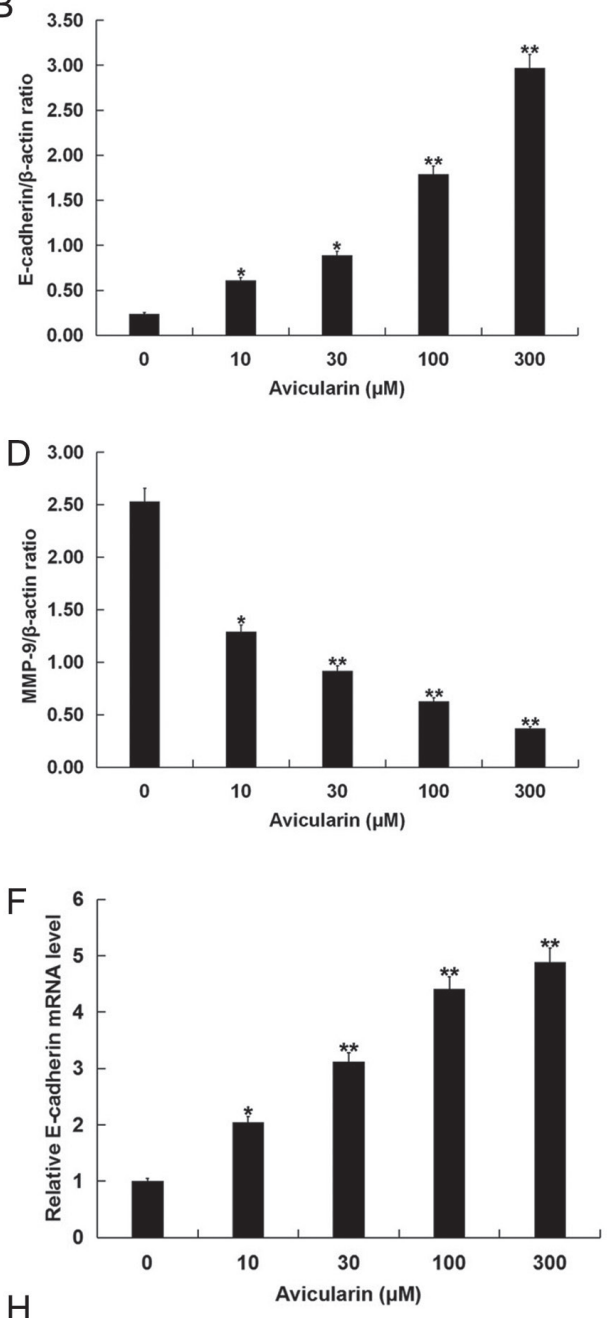

$\mathrm{H}$

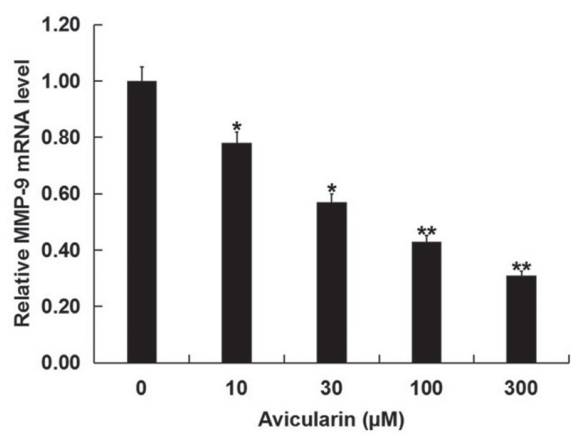

Figure 3. Avicularin regulates the expression levels of EMT-related genes in SCC13 cells. SCC13 cells were treated with different concentrations of avicularin $(0,10,30,100$ or $300 \mu \mathrm{M})$ for $48 \mathrm{~h}$. (A) Western blot analysis results of the protein expression levels of EMT-related genes. Quantification of the protein expression levels of (B) E-cadherin, (C) N-cadherin, (D) MMP-9 and (E) vimentin. Reverse-transcription-quantitative PCR results of the mRNA expression levels of (F) E-cadherin, (G) N-cadherin, (H) MMP-9 and (I) vimentin. Each experiment was performed at least three times. Data are presented as the mean \pm SD. ${ }^{*} \mathrm{P}<0.05,{ }^{* *} \mathrm{P}<0.01$ vs. $0 \mu \mathrm{M}$ avicularin. MMP-9, matrix metalloproteinase-9; EMT, epithelial-mesenchymal transition. 

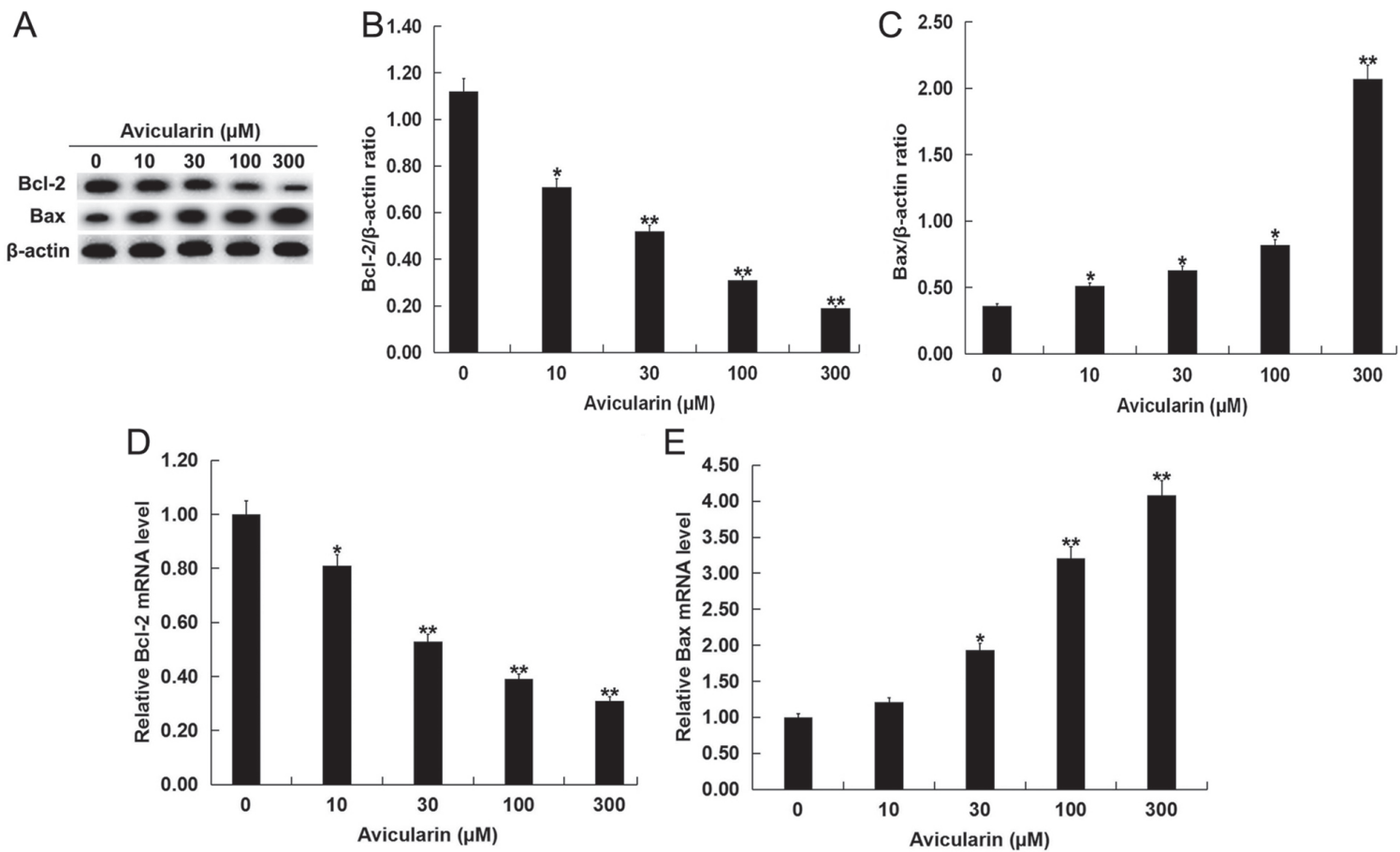

Figure 4. Avicularin regulates the expression levels of apoptosis-related genes. SCC13 cells were treated with different concentrations of avicularin $(0,10,30$, 100 or $300 \mu \mathrm{M}$ ) for $48 \mathrm{~h}$. (A) Western blot analysis and the quantification of the protein expression levels of (B) Bcl-2 and (C) Bax. Reverse transcription-quantitative PCR was used to detect (D) Bcl-2 and (E) Bax mRNA expression levels. Data are presented as the mean $\pm \mathrm{SD}$. ${ }^{*} \mathrm{P}<0.05,{ }^{* *} \mathrm{P}<0.01$ vs. $0 \mu \mathrm{M}$ avicularin.
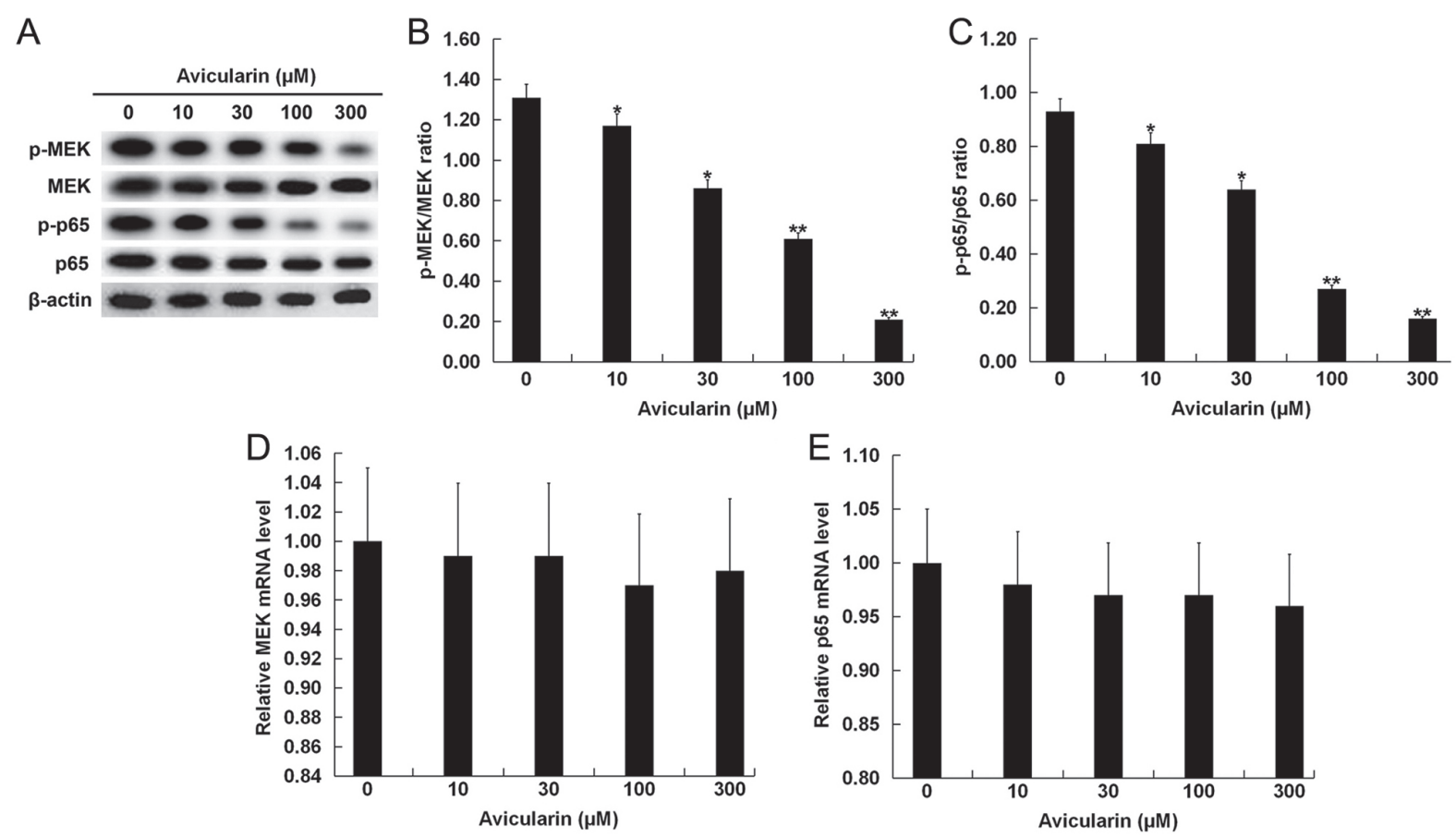

Figure 5. Avicularin regulates the MEK/NF- $\mathrm{BB}$ signaling pathway. SCC13 cells were treated with different concentrations of avicularin $(0,10,30,100$ or $300 \mu \mathrm{M}$ ) for $48 \mathrm{~h}$. (A) Western blot analysis results and the quantification of the protein expression levels of (B) p-MEK and MEK, and (C) p-p65 and p65. Reverse transcription-quantitative PCR was used to investigate the (D) MEK and (E) p65 mRNA expression levels. Data are presented as the mean \pm SD ${ }^{*} \mathrm{P}<0.05,{ }^{* *} \mathrm{P}<0.01$ vs. $0 \mu \mathrm{M}$ avicularin. MEK, mitogen-activated protein kinase kinase; $\mathrm{p}$-, phosphorylated.

glycoside forms (22). However, the biological activities of AL remain largely unknown. Quercetin has been shown to have a variety of beneficial effects such as suppression of neuronal apoptosis (23) and adipogenesis (24). Currently, the effect of $\mathrm{AL}$ on CSCC is not fully understood. Therefore, the present study investigated the effect of AL on CSCC to understand its biological activity and potentially facilitate the development of a theoretical basis for the treatment of CSCC.

The present study investigated the impact of $\mathrm{AL}$ on SCC13 cell viability and apoptosis. The present results 
suggested that AL inhibited cell viability and induced apoptosis in dose-dependent manner, indicating that AL induced cytotoxicity and apoptosis in CSCC cells. Subsequently, RT-qPCR and western blot analysis were used to detect the expression levels of genes related to EMT, including N-cadherin, E-cadherin, MMP-9 and vimentin to evaluate whether AL had an effect on the EMT of SCC13 cells. The present results suggested that AL increased E-cadherin expression level and decreased $\mathrm{N}$-cadherin, MMP-9 and vimentin expression levels in a dose-dependent manner; therefore, AL may regulate some biological functions in CSCC cells. Apoptosis is the main molecular mechanism of chemotherapy-induced cell death (25). Thus, defects in apoptosis can enhance resistance to chemotherapy and increase the survival rate of cancer cells (26). Bax is a major pro-apoptotic member of the Bcl-2 family, which regulates apoptosis in both cancer and healthy cells (27). Moreover, Bcl-2 is an essential antiapoptotic signal that can contribute to tumor growth $(28,29)$. To investigate whether AL was involved in the regulation of CSCC cell apoptosis, the present study analyzed the expression levels of Bax and Bcl-2 in SCC13 cells. The present results suggested that AL reduced Bcl-2 expression level, but increased Bax expression level in cells; therefore AL may induce CSCC cell apoptosis by regulating Bcl-2 and Bax. The present study investigated the signaling pathways involved in the effect of $\mathrm{AL}$ on CSCC by examining the expression levels of p-MEK and $\mathrm{p}-\mathrm{p} 65$, which are associated with the $\mathrm{MEK} / \mathrm{NF}-\kappa \mathrm{B}$ signal pathway $(30,31)$. The present results suggested that AL inhibited the activation of the $\mathrm{MEK} / \mathrm{NF}-\kappa \mathrm{B}$ signaling pathway, thus $\mathrm{AL}$ may have an anticancer role in CSCC.

In summary, the present results suggested that AL inhibited cell viability, induced apoptosis and prevented SCC13 cell EMT in a dose-dependent manner. The present results indicated that $\mathrm{AL}$ may repress the $\mathrm{MEK} / \mathrm{NF}-\kappa \mathrm{B}$ signaling pathway to regulate cell apoptosis-related and EMT-related genes in SCC13 cells. The present results may provide a theoretical basis for AL treatment of patients with CSCC. However, the present study is only a preliminary study of the effect of AL on CSCC, and further research is needed in other CSCC cell lines and in in vivo experiments. In addition, the $\mathrm{IC}_{50}$ of $\mathrm{AL}$ in CSCC cells should be determined and the molecular mechanism of $\mathrm{AL}$ inhibition of the $\mathrm{MEK} / \mathrm{NF}-\mathrm{\kappa B}$ requires further investigation.

\section{Acknowledgements}

Not applicable.

\section{Funding}

No funding was received.

\section{Availability of data and materials}

All data sets used and/or analyzed during the present study are available from the corresponding author on reasonable request.

\section{Authors' contributions}

YW contributed to study design, data collection, statistical analysis, data interpretation and manuscript preparation. MZL and SGC contributed to data collection and statistical analysis.
QW contributed to data collection, statistical analysis and manuscript preparation. All authors read and approved the final manuscript.

\section{Ethics approval and consent to participate}

Not applicable.

\section{Patient consent for publication}

Not applicable.

\section{Competing interests}

The authors declare that they have no competing interests.

\section{References}

1. McGuire JF, Ge NN and Dyson S: Nonmelanoma skin cancer of the head and neck I: Histopathology and clinical behavior. Am J Otolaryngol-Head Neck Med Surg 30: 121-133, 2009.

2. Martinez JC and Cook JL: High-risk cutaneous squamous cell carcinoma without palpable lymphadenopathy: Is there a therapeutic role for elective neck dissection? Dermatol Surg 33: 410-420, 2007.

3. Weinberg AS, Ogle CA and Shim EK: Metastatic cutaneous squamous cell carcinoma: An update. Dermatol Surg 33: 885-899, 2007.

4. Venables ZC, Nijsten T, Wong KF, Autier P, Broggio J, Deas A, Harwood CA, Hollestein LM, Langan SM, Morgan E, et al: Epidemiology of basal and cutaneous squamous cell carcinoma in the U.K. 2013-15: A cohort study. Br J Dermatol 181: 474-482, 2019.

5. Trakatelli M, Ulrich C, Del Marmol V,Euvrard S, Stockfleth E and Abeni D: Epidemiology of nonmelanoma skin cancer (NMSC) in Europe: Accurate and comparable data are needed for effective public health monitoring and interventions. Br J Dermatol 156: $1-7,2007$.

6. Alam M and Ratner D: Cutaneous squamous-cell carcinoma. N Engl J Med 344: 975-983, 2001.

7. Langer CJ: Targeted therapy in head and neck cancer: State of the art 2007 and review of clinical applications. Cancer 112: 2635-2645, 2008.

8. Argiris A, Karamouzis MV, Raben D and Ferris RL: Head and neck cancer. Lancet 371: 1695-1709, 2008.

9. Trodello C, Pepper JP, Wong M and Wysong A: Cisplatin and cetuximab treatment for metastatic cutaneous squamous cell carcinoma: A systematic review. Dermatol Surg 43: 40-49, 2017.

10. YangL,WuS,ZhangQ,LiuFandWuP:23,24-Dihydrocucurbitacin $\mathrm{B}$ induces $\mathrm{G} 2 / \mathrm{M}$ cell-cycle arrest and mitochondria dependent apoptosis in human breast cancer cells (Bcap37). Cancer Lett 256: 267-278, 2007.

11. Buqui GA, Gouvea DR, Sy SK, Voelkner A, Singh RS, da Silva DB, Kimura E, Derendorf H, Lopes NP and Diniz A: Pharmacokinetic evaluation of avicularin using a model-based development approach. Planta Med 81: 373-381, 2015.

12. Fujimori K and Shibano M: Avicularin: A plant flavonoid, suppresses lipid accumulation through repression of C/EBP $\alpha$-activated GLUT4-mediated glucose uptake in 3T3-L1 cells. J Agric Food Chem 6: 5139-5147, 2013.

13. Vo VA, Lee JW, Chang JE, Kim JY, Kim NH, Lee HJ, Kim SS, Chun W and Kwon YS: Avicularin inhibits lipopolysaccharide-induced inflammatory response by suppressing ERK phosphorylation in RAW 264.7 macrophages. Biomol Ther 20: 532,2012 .

14. Zhang WM, Li RF, Sun M, Hu DM, Qiu JF and Yan YH: UPLC-MS/MS method for determination of avicularin in rat plasma and its application to a pharmacokinetic study. J Chromatogr B Analyt Technol Biomed Life Sci 965: 107-111, 2014.

15. Zhu X, Ouyang W, Miao J, Xiong P, Feng K, Li M, Cao Y and Xiao H: Dietary avicularin alleviated type 2 diabetes in mice. FASEB J 31: 46-47, 2017. 
16. Srivastava S, Somasagara RR, Hegde M, Nishana M, Tadi SK, Srivastava M, Choudhary B and Raghavan SC: Quercetin, a natural flavonoid interacts with DNA, arrests cell cycle and causes tumor regression by activating mitochondrial pathway of apoptosis. Sci Rep 6: 24049, 2016.

17. Wang W, Zheng H, Zheng M, Liu X and Yu J: Protective effect of avicularin on rheumatoid arthritis and its associated mechanisms. Exp Ther Med 16: 5343-5349, 2018.

18. Ghasemzadeh A and Ghasemzadeh N: Flavonoids and phenolic acids: Role and biochemical activity in plants and human. J Med Plants Res 5: 6697-6703, 2011.

19. Livak KJ and Schmittgen TD: Analysis of relative gene expression data using real-time quantitative PCR and the 2(-Delta Delta C(T)) method. Methods 25: 402-408, 2001

20. Schenk RL, Strasser A and Dewson G: BCL-2: Long and winding path from discovery to therapeutic target. Biochem Biophys Res Commun 482: 459-469, 2017.

21. Sharififar F, Dehghn-Nudeh G and Mirtajaldini M: Major flavonoids with antioxidant activity from Teucrium polium L. Food Chem 112: 885-888, 2009.

22. Panche AN, Diwan AD and Chandra SR: Flavonoids: An overview. J Nutr Sci 5: e47, 2016.

23. Suematsu N, Hosoda M and Fujimori K: Protective effects of quercetin against hydrogen peroxide-induced apoptosis in human neuronal SH-SY5Y cells. Neurosci Lett 504: 223-227, 2011.

24. Ahn J, Lee H, Kim S, Park J and Ha T: The anti-obesity effect of quercetin is mediated by the AMPK and MAPK signaling pathways. Biochem Biophys Res Commun 373: 545-549, 2008.

25. Cotter TG: Apoptosis and cancer: The genesis of a research field. Cancer 9: 501-507, 2009.
26. Wong RS: Apoptosis in cancer: From pathogenesis to treatment J Exp Clin Cancer Res 30: 87, 2011.

27. Kim H, Tu HC, Ren D, Takeuchi O, Jeffers JR, Zambetti GP Hsieh JJ and Cheng EH: Stepwise activation of BAX and BAK by tBID, BIM, and PUMA initiates mitochondrial apoptosis. Mol Cell 36: 487-499, 2009.

28. Leverson JD, Phillips DC, Mitten MJ, Boghaert ER, Diaz D, Tahir SK, Belmont LD, Nimmer P, Xiao Y, Ma XM, et al: Exploiting selective BCL-2 family inhibitors to dissect cell survival dependencies and define improved strategies for cancer therapy. Sci Transl Med 7: 279ra40, 2015.

29. Han L, Zhang EB, Yin DD, Kong R, Xu TP, Chen WM, Xia R, Shu YQ and De W: Low expression of long noncoding RNA PANDAR predicts a poor prognosis of non-small cell lung cancer and affects cell apoptosis by regulating Bcl-2. Cell Death Dis 6: e1665, 2015 .

30. van der Noord VE, McLaughlin RP, Smid M, Foekens JA, Martens JWM, Zhang Y and van de Water B: An increased cell cycle gene network determines MEK and Akt inhibitor double resistance in triple-negative breast cancer. Sci Rep 9: 13308, 2019.

31. Lawrence T: The nuclear factor NF-kappaB pathway in inflammation. Cold Spring Harb Perspect Biol 1: a001651, 2009.

(i) $\odot$ This work is licensed under a Creative Common Attribution-NonCommercial-NoDerivatives 4.0 International (CC BY-NC-ND 4.0) License. 